The insurer's action is bound to have a chilling effect on physicians doing this work, says Colleen Flood, Canada Research Chair in Health Law and Policy at the University of Toronto. This in turn will make it even more difficult for families who want to use donors, says Kelly Jordan, a Toronto fertility lawyer.

The lawsuit was filed in March in Florida. Despite signed agreements between Gilman and both the Toronto West Fertility Centre and CReATe, which stipulate that any disputes must be settled in Ontario, Gilman's lawyer,
Rufus Pennington, is arguing that the case should be heard in Florida. By coincidence, Ryan travelled to Florida for a holiday on the same day Gilman returned home after her retrieval. In the hours leading up to her stroke, according to Gilman, Ryan provided medical advice by cellphone to Gilman. "By giving medical advice to his patient while he was physically located within the state of Florida," says Pennington, "Dr. Ryan subjected himself to the jurisdiction of the Florida courts."
According to court filings, Ryan only learned of his insurer's decision not to defend him when he was served with a motion for default for failing to respond to the lawsuit in a timely fashion. The insurer had initially assigned a lawyer to his case but later withdrew him. A Florida judge will now decide whether to set the default aside and allow the case to proceed, as Ryan's lawyer has requested. - Alison Motluk, Toronto, Ont.

CMAJ 2013. DOI:10.1503/cmaj.109-4604

\title{
Suicide prevention training saves lives in Nunavut
}

$\mathrm{T}$ he evening Junior Kopak finished a two-day workshop on suicideprevention for Inuit youth in Ottawa, Ontario, he saved his first life.

It was a Thursday in March 2012. A friend from Nunavut, visiting Ottawa on a high school trip, met Kopak downtown. Fresh from his Applied Suicide Intervention Skills Training (ASIST) workshop, Kopak noticed his friend was drinking more than usual, and crying. She blamed herself for arguing with two close family members, in separate incidents, shortly before each committed suicide. One hanged herself two years earlier, and the other killed himself six years previously.

Kopak, 20, was alarmed by what his friend said. So he did what ASIST trained him to do. He asked his friend if she was thinking of ending her life.

She told him she planned to kill herself when she arrived back in Nunavut.

Kopak felt overwhelmed. He worried about saying or doing something to inadvertently push his friend over the mental precipice she straddled. But he had already lost too many people he loved to suicide.

So, he followed the steps ASIST lays out. The internationally acclaimed program - developed by the company LivingWorks, based in Calgary, Alberta is designed to help anyone apply mental health first aid by intervening directly to prevent the immediate risk of suicide. The program, which has trained more than a million caregivers and is used in 15 countries around the world, involves

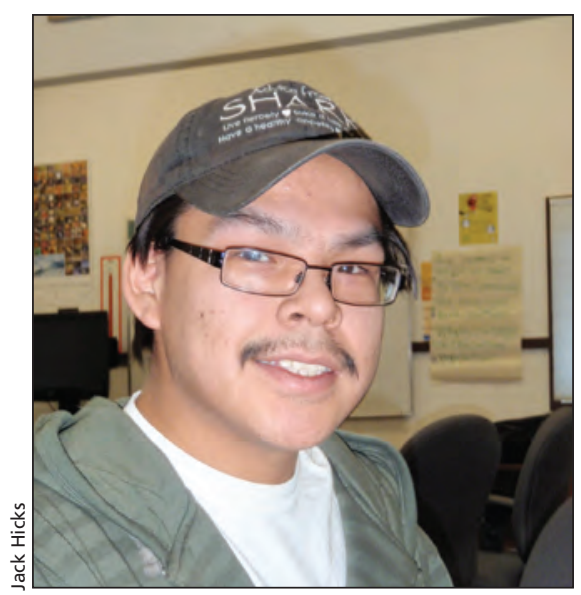

Junior Kopak, who lives in Repulse Bay, Nunavut, used the training he received at an Applied Suicide Intervention Skills Training workshop to save a suicidal friend's life. The course is one of the components of Nunavut's Suicide Prevention Strategy Action plan.

identifying risk, developing a safety plan and directing someone in crisis to further professional mental health support.

The special version of the course that Kopak took, specifically designed for life in Nunavut, is a critical component of the Government of Nunavut's three-year-old Suicide Prevention Strategy and two-year-old Action Plan.

That night in Ottawa, Kopak took a deep breath. Then he dove in to help his friend.

"I listened to her talk," he remembers. "I made sure she was finished talking. Then I said to her, 'I took this course, and I think I can help you.",

The two walked around downtown Ottawa. They talked. Once the young woman was calm, Kopak pulled out his green and white ASIST card.

"Right then and there, she trusted me," Kopak says from Repulse Bay, Nunavut, where he now lives.

With the help of the card, he guided his friend through a process that involves confronting the risk directly. After identifying the ambivalence people who disclose suicidal intentions feel, the intervener helps the person in crisis articulate reasons they have to live, as well as reasons they want to die. After helping his friend appreciate her reasons for living, Kopak suggested resources. They made a safety plan, which involved trying to get counselling and talking to her parents.

Kopak was unable to follow up in person with his friend, as ASIST directs, because he remained in Ottawa while she returned to Nunavut. But he made sure they continued to talk. A year later, she was not only alive, she had a powerful reason to live: a new baby.

Increasingly, First Nations communities with high rates of suicide, like the Siksika Nation in Alberta, are also making ASIST and a shorter version of its suicide awareness training, called safeTALK, a core of their prevention approaches. Siksika's goal is to have someone in every third house on Canada's second-largest reserve trained in safeTALK, says Marsha Wolf Collar, the mental health coordinator with Siksika Health Services.

"If we can have every other home or every third home trained in safeTALK, then that's a protective factor," Wolf Collar says. "It would probably be 
costly, but it's an investment in our community."

Alberta Health Services recently used ASIST to train about 650 people to help prevent suicide in Aboriginal communities across the province. Four staff members have become ASIST trainers and have delivered workshops for 36 groups in First Nation and Métis communities there, often in partnership with Aboriginal health and addictions and mental health programs.

In Ontario, the Nishnawbe Aski Nation is also offering ASIST training to representatives from the 49 First Nations in northern Ontario that the political organization represents. Many of those communities have extremely high suicide rates. The organization views training support workers as "a suicide first aid support for the community," Loretta Sheshequin, coordinator of the organization's Life Promotion Project, said in a statement.

In many of the Inuit and Aboriginal communities using the program, lifesaving stories are emerging. Kopak's successful application of ASIST is one of half a dozen such successful interventions since the program kicked off in Nunavut. Another young woman successfully used her training the same day she graduated from an ASIST workshop in Pangnirtung, she told ASIST trainer Jack Hicks.

"We don't know how many other stories there are that we don't know, of course," says Hicks, a PhD candidate and expert in Inuit suicide research. LivingWorks does not collect statistics about the number of times those trained in ASIST successfully intervene to save lives, and those interventions are confidential.

Still another ASIST graduate was working in her government office when she received a text from a man who would not identify himself or tell her where he was. When she determined he was suicidal, she worked the ASIST steps via text for three hours. She stopped only when they had developed a plan and she decided he was out of immediate danger.

Samantha Barnes, a counsellor at one of Iqaluit's elementary schools, also used her ASIST training to intervene not with a student, which was the reason she took the course, but with a suicidal family member.

"It kept me calm and kept who I was helping calm," Barnes says of her training. She was able to get her family member additional help.

For Kopak, savings his friend's life not only made him feel "on top of the world," it helped him put in perspective his grief about the suicides that are an ever-present feature of the lives of Nunavummiut.

"After taking ASIST, I feel there's more to life than committing suicide," says Kopak. "I feel like I can help more than I did [when I was] back in high school." - Laura Eggertson, Iqaluit, Nunavut, and on the Siksika First Nation, Alberta

CMAJ 2013. DOI:10.1503/cmaj.109-4595

Editor's note: This is the fourth of a series on suicide in Nunavut, Canada; the other stories can be read at cmaj.ca. Laura Eggertson received a 2012 Michener-Deacon Fellowship for Investigative Journalism award, which supported her travel and the research into this series of articles about suicide by Inuit and First Nations youth.

\section{More News online}

Acid attack victims in Cambodia: Cambodia has a history of acid attacks and recovery is rare. - Brendan Brady, Phnom Penh, Cambodia

New tuberculosis drug targets resistant tuberculosis: The World Health Organization has released interim guidelines for using bedaquiline to treat multidrug-resistant tuberculosis. - Amelia Wilkinson, CMAJ

Risk of suicide for Inuit boys: Inuit males aged 15-19 killed themselves at a rate 40 times greater than the rate for non-Inuit males in the same age group. - Laura Eggertson, Iqaluit, Nunavut

Inuit leaders announce suicide-prevention strategy: Inuit leaders are creating their own suicide-prevention strategy for Inuit people across Canada. — Laura Eggertson, CMAJ

Risk of tick-borne infections on the rise: Canadians should be prepared for an increase in the rates of tick-borne diseases like Lyme disease. Brian Owens, St. Stephen, NB

Ubiquitous preservative blamed for rash of skin allergies: The British Association of Dermatologists calls for a ban on a preservative it blames for an "epidemic" of allergic contact dermatitis. - Catherine Cross, CMAJ

Scientists, supporters rally in Canadian cities: Scientists and supporters demonstrated across Canada, calling for more basic research and evidence-based policies. — Laura Eggertson, Iqaluit, Nunavut

UK Health Check contradicts best evidence: The UK's Health Check program was created to help prevent heart disease and other ailments but critics say it is unproven. - Neil Chanchlani, MD, London, UK

Dental care too expensive for many middle-income Canadians: Many middle-income Canadians are finding it difficult to visit the dentist because they can't afford it. - Catherine Cross, CMAJ

CMAJ 2013. DOI:10.1503/cmaj.109-4598 cmaj.ca 